\title{
Connecting Type 1 and Type 2 Diabetes through Innate Immunity
}

\author{
Justin I. Odegaard ${ }^{1}$ and Ajay Chawla ${ }^{2}$ \\ ${ }^{1}$ Department of Pathology, Stanford University School of Medicine, Stanford, California 94305 \\ ${ }^{2}$ Cardiovascular Research Institute, Department of Physiology, and Department of Medicine, \\ University of California, San Francisco, San Francisco, California 94158 \\ Correspondence: ajay.chawla@ucsf.edu
}

\begin{abstract}
The escalating epidemic of obesity has driven the prevalence of both type 1 and 2 diabetes mellitus to historically high levels. Chronic low-grade inflammation, which is present in both type 1 and type 2 diabetics, contributes to the pathogenesis of insulin resistance. The accumulation of activated innate immune cells in metabolic tissues results in release of inflammatory mediators, in particular, IL-1 $\beta$ and TNF $\alpha$, which promote systemic insulin resistance and $\beta$-cell damage. In this article, we discuss the central role of innate immunity and, in particular, the macrophage in insulin sensitivity and resistance, $\beta$-cell damage, and autoimmune insulitis. We conclude with a discussion of the therapeutic implications of this integrated understanding of diabetic pathology.
\end{abstract}

$T^{\text {he }}$ he past 30 years have borne witness to one of the most dramatic phenotypic shifts in humankind's history. We have, in an evolutionary eyeblink, become fat. Within a single generation, the obesity epidemic has swept from Western cultures into the developing world, leaving behind an estimated 1.5 billion overweight individuals, of which 500 million are clinically obese (Flegal et al. 2010). The public health burden associated with our waxing waistlines is staggering. In 2000 alone, an estimated 400,000 people died from obesity-related diseases in the United States alone, putting obesity on par with smoking in terms of lives lost (Mokdad et al. 2004, 2005).

These grim trends have been more quietly paralleled by a similarly dramatic increase in type 1 diabetes incidence. Type 1 diabetes incidence has more than doubled in the past 20 years and is set to double again before 2020 (Patterson et al. 2009). Unexpectedly, however, the surplus incidence is not uniformly distributed. The incidence of type 1 diabetes in highrisk HLA types over the past 20 years has remained stable, whereas the contemporaneous incidence in medium-, low-, and very-low-risk genotypes has increased by twofold, threefold, and sevenfold, respectively (Fourlanos et al. 2008b). Importantly, these "surplus" type 1 diabetics show a remarkable tendency toward obesity and insulin resistance, often meeting full criteria for type 2 diabetes and mimicking the trends seen in obesity-related type 2 diabetes (Fourlanos et al. 2008b). Indeed, prospective

Editors: Jeffrey A. Bluestone, Mark A. Atkinson, and Peter R. Arvan

Additional Perspectives on Type 1 Diabetes available at www.perspectivesinmedicine.org

Copyright (C) 2012 Cold Spring Harbor Laboratory Press; all rights reserved; doi: 10.1101/cshperspect.a007724

Cite this article as Cold Spring Harb Perspect Med 2012;2:a007724 
cohort studies have shown that children who go on to develop type 1 diabetes are heavier than their peers who remain free of disease (Baum et al. 1975; Johansson et al. 1994; Hypponen et al. 1999, 2000; Bruining 2000) and that within type 1 diabetics, increasing BMI strongly correlates with earlier presentation (Kibirige et al. 2003; Betts et al. 2005; Knerr et al. 2005; Kordonouri and Hartmann 2005; Dabelea et al. 2006). Moreover, obesity-related insulin resistance not only precedes clinical disease but is also the strongest predictor of type 1 diabetes aside from HLA genotype (Baum et al. 1975; Johansson et al. 1994; Hypponen et al. 1999, 2000; Bruining 2000; Xu et al. 2007; Fourlanos et al. 2008a). Finally, insulin-sensitizing drugs and interventions (e.g., weight loss, exercise) are effective in preventing, delaying, and even partially reversing type 1 disease (Kjems et al. 2003; Miller and Silverstein 2006; Kilpatrick et al. 2007; Moon et al. 2007; Neovius et al. 2008).

These data exemplify fundamental shifts in diabetes demographics in which expanding Western waistlines have blurred the once crisp distinction between type 1 and type 2 diabetes mellitus. Indeed, Himsworth's world in which type 1 diabetes was epitomized by the spindly child and type 2 diabetes limited to the corpulent middle-aged gourmand no longer exists (Himsworth 1939). Some recent series, for example, record more than half of all newly diagnosed type 1 diabetics as adults, many of whom meet criteria for metabolic syndrome (Molbak et al. 1994; Thorn et al. 2005), whereas type 2 diabetes is now a common disease of children, many of whom are positive for anti- $\beta$-cell antibodies. The startling prevalence of patients, children in particular, meeting criteria for both type 1 and type 2 diabetes has left a confused flurry of vague terminology in its wake: "double diabetes," "type 1.5 diabetes," "hybrid diabetes," "latent autoimmune diabetes of the young (LADY) and of the adult (LADA)," and so on (Pozzilli and Guglielmi 2009; Wilkin 2009). Irrespective of classification schema, the advent of near-ubiquitous obesity has expanded the once tight circles of type 1 and type 2 diabetes to a degree that obesity-related insulin resis- tance has become a driving etiologic force across the diabetes spectrum.

Recognition of insulin resistance's catastrophic health sequelae has engendered intense interest in its pathophysiology and led to the identification of literally hundreds of dietary, behavioral, and environmental disease modifiers (Kahn and Flier 2000; Shulman 2000; Wellen and Hotamisligil 2005, 2006; Qatanani and Lazar 2007; Olefsky and Glass 2010). Despite the daunting complexity of inputs and modifiers, the vast majority converge on a single sentinel pathophysiology: chronic, low-level inflammation (Hotamisligil 2006; Shoelson et al. 2006; Odegaard and Chawla 2008; Olefsky and Glass 2010; Lumeng and Saltiel 2011). In this context, innate immunity has emerged as a primary determinant of obesity-related pathology including the full spectrum of diabetic disease. In this article, we discuss the central role of innate immunity - and of the macrophage, in particular-in insulin sensitivity and resistance, $\beta$-cell damage, and autoimmune insulitis. We conclude with a discussion of the therapeutic implications of this integrated understanding of diabetic pathology.

\section{INSULIN PRODUCTION AND INSULIN RESISTANCE}

Glucose homeostasis is generally achieved through a balance of input (e.g., dietary, gluconeogenesis) and tissue uptake/utilization (e.g., storage as fat/glycogen or oxidation) coordinated by the $\beta$-cells of the pancreas through the production of insulin (Saltiel and Kahn 2001; Taniguchi et al. 2006; Qatanani and Lazar 2007). Insulin itself is a polypeptide with diverse and pleiotropic effects across nearly every tissue type in the body, where, in addition to its wellappreciated metabolic effects, it also regulates fundamental cellular programs like growth, proliferation, and apoptosis (Taniguchi et al. 2006). With regard to glycemia, however, three target tissues have primacy: fat, liver, and skeletal muscle (Saltiel and Kahn 2001). These organs represent an individual's primary storage, production, and oxidation pathways, respectively, and together modulate glycemia. As sites 
of insulin's metabolic action, these same tissues are also the primary determinants of insulin resistance (Kahn and Flier 2000; Shulman 2000; Qatanani and Lazar 2007). However, although the base effect is shared among them, insulin resistance in each specific tissue manifests itself clinically in very different ways. For example, insulin resistance in the liver is responsible for elevated fasting serum glucose, a key clinical criterion for the diagnosis of type 2 diabetes, owing to the inability of insulin to suppress hepatic gluconeogenesis while lipid biosynthesis remains intact (Brown and Goldstein 2008). In contrast, insulin resistance in adipose tissue and skeletal muscle manifests as elevated lipolysis and glucose intolerance, respectively, resulting in hyperlipidemia, hyperglycemia, and compensatory hyperinsulinemia (Kahn and Flier 2000; Shulman 2000).

\section{INSULIN RESISTANCE AND $\beta$-CELL LOSS}

The pancreas itself is another target of insulin resistance, albeit in an indirect fashion. With mounting insulin resistance, blood glucose concentrations progressively rise because of the functional loss of insulin action in the periphery, which, in turn, leads to compensatory and progressive hyperinsulinemia. The natural history of this pathophysiology is mounting $\beta$-cell stress, eventual $\beta$-cell exhaustion, and frank diabetes (Kahn and Flier 2000; Shulman 2000). In support of this, many recent candidate genes implicated in type 2 diabetes by genome-wide association studies (e.g., INS, KCNJ11, and TCF7L2) are expressed not in insulin target tissues but in the islet itself (McCarthy and Hattersley 2008). This denouement of insulin resistance has always been seen as the end-stage pathology of type 2 diabetes; however, evidence reviewed elsewhere in this collection shows that this pathway operates in parallel with, and licenses immune destruction of, $\beta$-cell mass across the diabetes spectrum.

Three mechanisms in particular couple insulin resistance to $\beta$-cell depletion and, indirectly, immune attack: glucotoxicity, lipotoxicity, and inflammation (Fig. 1). The elevated levels of glucose and lipids, particularly satu- rated fatty acids, that are characteristic of insulin resistance synergize at the level of the $\beta$-cell to drive parallel increases in FAS expression, activating NK cell ligands (e.g., RAE-1, NKp46ligand), reactive oxygen species, and endoplasmic reticulum (ER) stress, all of which culminate in IL-1 $\beta$ secretion and apoptosis (Lee et al. 1994; Unger 1995; Harding and Ron 2002; Ogasawara et al. 2004; Hotamisligil 2010; Mandrup-Poulsen et al. 2010). Importantly, IL- $1 \beta$ has been a known mediator of $\beta$-cell dysfunction and death for more than 25 years (Mandrup-Poulsen et al. 1985) and is potentiated by TNF $\alpha$ and IFN $\gamma$ (Eizirik 1988; Pukel et al. 1988), both of which are present at high levels under conditions of insulin resistance. Indeed, $\beta$-cells are uniquely susceptible to IL-1 $\beta$ 's effects as they express higher levels of IL-1R1 than any other cell type in the body (BoniSchnetzler et al. 2009). Engagement of the IL$1 \mathrm{R} 1$ results in activation of NF- $\kappa \mathrm{B}, \mathrm{MAPK}$, $\mathrm{PKC} \delta$, and JNK signaling pathways (Maedler et al. 2011), resulting in direct promotion of apoptosis and FAS up-regulation (Elouil et al. 2005), as well as the inhibition of insulin signaling, which is critical for optimal $\beta$-cell function (Maedler et al. 2011). In addition, IL-1 $\beta$ signaling results in the production of pro-inflammatory mediators that act in a feed-forward autocrine/paracrine manner in $\beta$-cells and local innate immune cells to amplify these effects.

The net result of these processes is an islet microenvironment replete with a damaged and vulnerable $\beta$-cell mass, copious antigenic $\beta$ cell debris, and a phlogistically primed local innate immune response. The denouement of this inflammatory milieu is the licensing of a lymphocyte-driven autoimmune assault on the remaining $\beta$-cell pool. Whether this licensing occurs early in the disease course, when much of the $\beta$-cell mass remains (typical in type 1 diabetes), or late, after much of the $\beta$ cell mass has been degraded by long-standing insulin resistance (typical in type 2 diabetes), it is clear that the terminal mechanisms of $\beta$-cell failure are identical. As such, the coupling of insulin resistance to exhaustion, direct toxicity, and autoimmune destruction of the $\beta$ cell provides a mechanism by which the obesity 
J.I. Odegaard and A. Chawla

A Insulin sensitivity

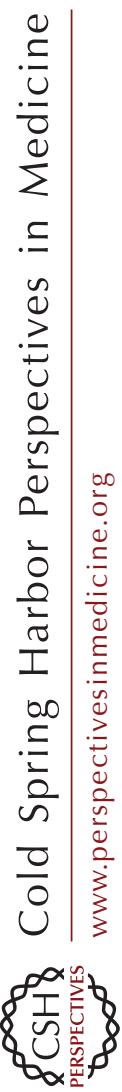

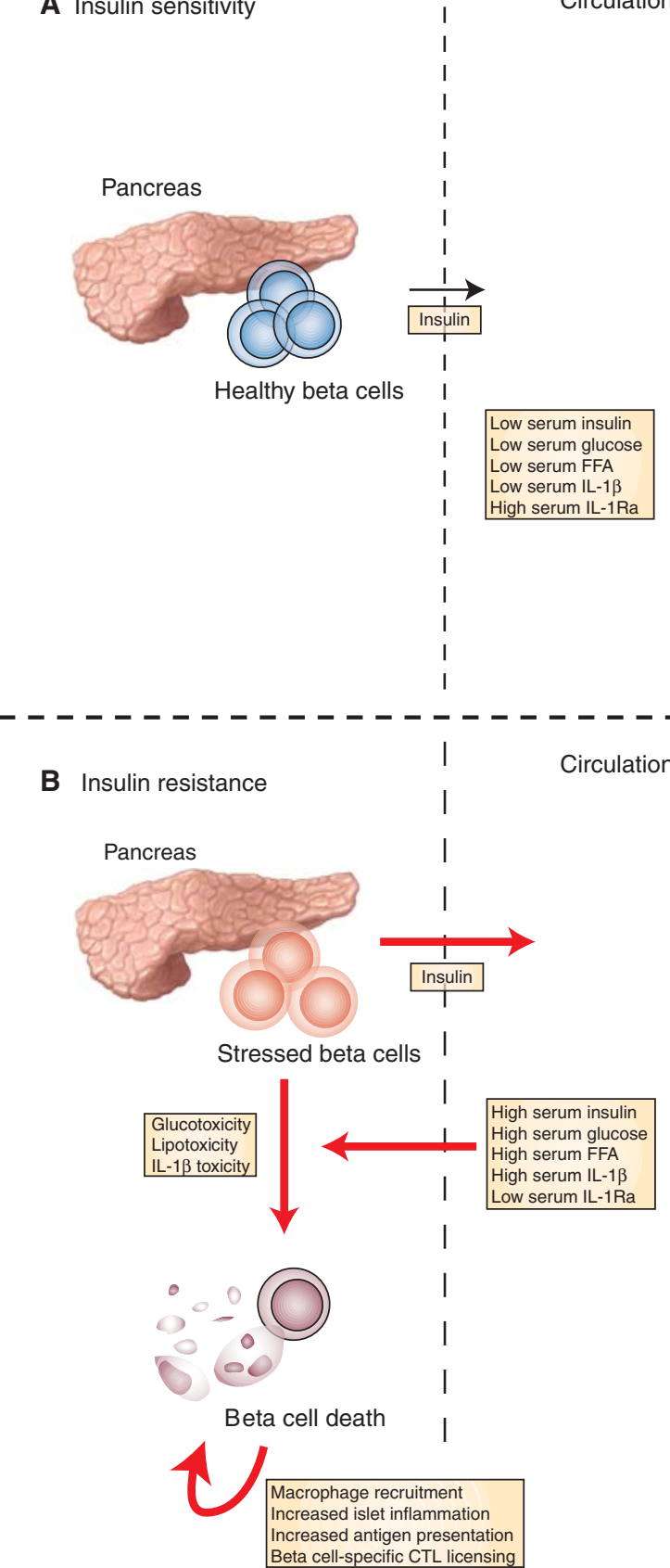
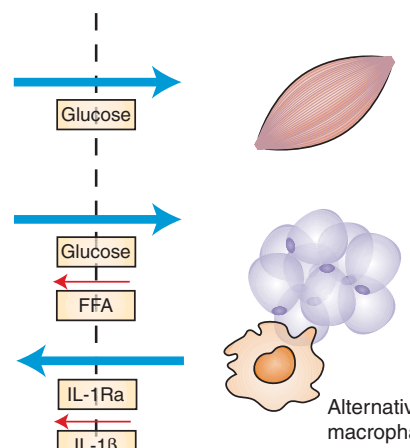

Skeletal muscle
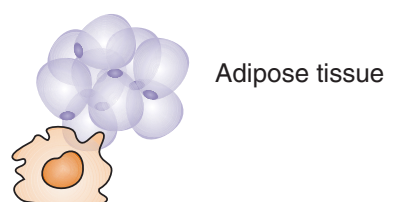

Alternatively activated macrophage
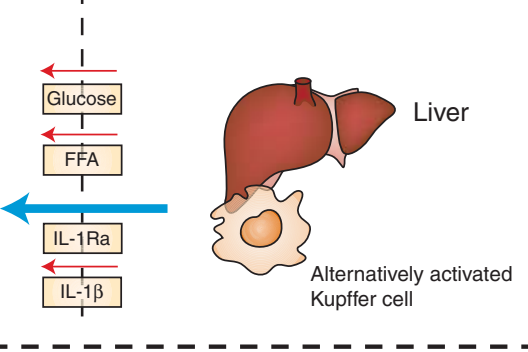

- -

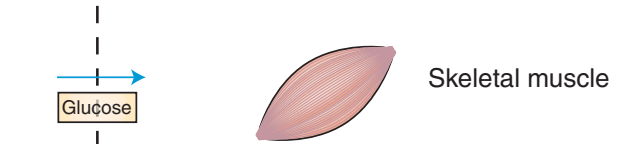

Figure 1. Insulin resistance damages $\beta$-cells and leads to autoimmune insulitis. ( $A$ ) In lean, insulin-sensitive individuals, normal insulin secretion is sufficient to induce robust uptake of glucose from the circulation by skeletal muscle and adipose tissue, to inhibit free fatty acid (FFA) release from adipose tissue, and to suppress hepatic gluconeogenesis. In such individuals, the adipose tissue macrophages and Kupffer cells have an alternative bias, resulting in expression of interleukin-1 receptor antagonist (IL1-Ra) and suppression of IL-1 $\beta$. The resulting serologic state is characterized by relatively low concentrations of insulin, glucose, FFAs, and inflammatory mediators (e.g., IL-1 $\beta$ ) and high levels of regulatory cytokines (e.g., IL-1Ra). (See facing page for legend.) 
epidemic is driving the incidence of both type 1 and type 2 diabetes to historic levels.

\section{INFLAMMATION AND INSULIN RESISTANCE}

These data advance insulin resistance to the fore as one of the primary pathophysiological determinants of diabetes, and considerable effort has been expended to define the mechanisms and origins of this process (Kahn and Flier 2000; Shulman 2000; Hotamisligil 2003; Odegaard and Chawla 2008; Olefsky and Glass 2010). These determinants can be classified into cell intrinsic and extrinsic effects. Broadly speaking, cell-intrinsic effects comprise ER stress, intracellular lipid deposition/imbalance, mitochondrial dysfunction, oxidative stress, and anabolic demand, whereas circulating cytokines and adipokines, serum fatty acid composition, and hypoxia are the dominant extrinsic pathways that modulate peripheral insulin signaling (Qatanani and Lazar 2007). Despite their biological diversity, a striking majority of these determinants converge on the common pathway of inflammation. Both cell-intrinsic and cell-extrinsic pathways drive intracellular signaling cascades that converge on one or more of a handful of key inflammatory mediators, which, in turn, directly impinge on the insulin signaling pathway (Hotamisligil 2006). As represented in Figure 2, inflammatory cytokines, saturated fatty acids, hypoxia, and ER stress converge on inhibitor of nuclear factor- $\kappa \mathrm{B}$ (NF$\kappa \mathrm{B})$, kinase- $\beta$ (IKK $\beta)$, and Jun kinase (JNK) to directly inhibit insulin action via serine phosphorylation of insulin receptor substrate 1 and 2 (IRS-1 and IRS-2) (Yuan et al. 2001; Hirosumi et al. 2002; Arkan et al. 2005; Cai et al. 2005). In addition, activation of NF- $\kappa \mathrm{B}$ and $\mathrm{AP}-1$ transcription factors by these kinases activates transcription of inflammatory cytokines and establishes an autocrine/paracrine feed-forward loop of inflammation (Wellen and Hotamisligil 2005). Similarly, cytokines and adipokines activate multiple suppressor of cytokine signaling (SOCS) proteins (notably SOCS3), which interfere with activating tyrosine phosphorylation of IRS-1 and IRS-2 and target them for proteasomal degradation (Qatanani and Lazar 2007). Irrespective of the precise signaling mechanism, the net effect is a broad and potent inhibition of intracellular insulin signal transduction. Because a full mechanistic discussion of these determinants is beyond the scope of this article (Qatanani and Lazar 2007; Hotamisligil 2010; Lumeng and Saltiel 2011), we focus on metabolic inflammation as a common pathway by which these protean effects drive insulin resistance.

Although the connection between inflammation and insulin resistance has been postulated for decades, the first direct evidence emerged in the early 1990s with the demonstration that $\mathrm{TNF} \alpha$, a known inflammatory mediator, was (1) present in fat in levels proportional to insulin resistance in obese animals and individuals, (2) necessary for obesity-related insulin resistance, and (3) sufficient to recapitulate insulin resistance in lean, otherwise insulin-sensitive animals (Hotamisligil et al. 1993, 1996). These seminal findings firmly established the relationship between insulin resistance and inflammation within the fat and unleashed a torrent of association studies indicting insulin

Figure 1. (Continued) (B) In contrast, insulin resistance abrogates insulin's peripheral effects, resulting in reduced glucose uptake, unsuppressed hepatic gluconeogenesis, and enhanced FFA release from adipose tissue. Under these conditions, adipose tissue macrophages and Kupffer cell populations are classically activated, expressing high levels of pro-inflammatory mediators such as IL-1 $\beta, T N F \alpha$, and nitric oxide, while suppressing production of tolerogenic peptides, such as IL-10 and IL-1Ra. The serum is thus characterized by progressively higher levels of insulin, glucose, FFAs, and inflammatory mediators and reduced levels of tolerogenic peptides. Escalating insulin resistance eventually results in levels of glucose, saturated fatty acids, and inflammatory mediators that are directly toxic to $\beta$-cells (among other tissues). $\beta$-Cell damage and concomitant innate immune activation within the islet initiate $\beta$-cell-specific cytotoxic T lymphocyte (CTL) responses, which further damage the beleaguered $\beta$-cells. (Blue) Processes associated with insulin sensitivity; (red) those associated with insulin resistance. The arrow weight indicates relative flux through individual pathways. 
J.I. Odegaard and A. Chawla

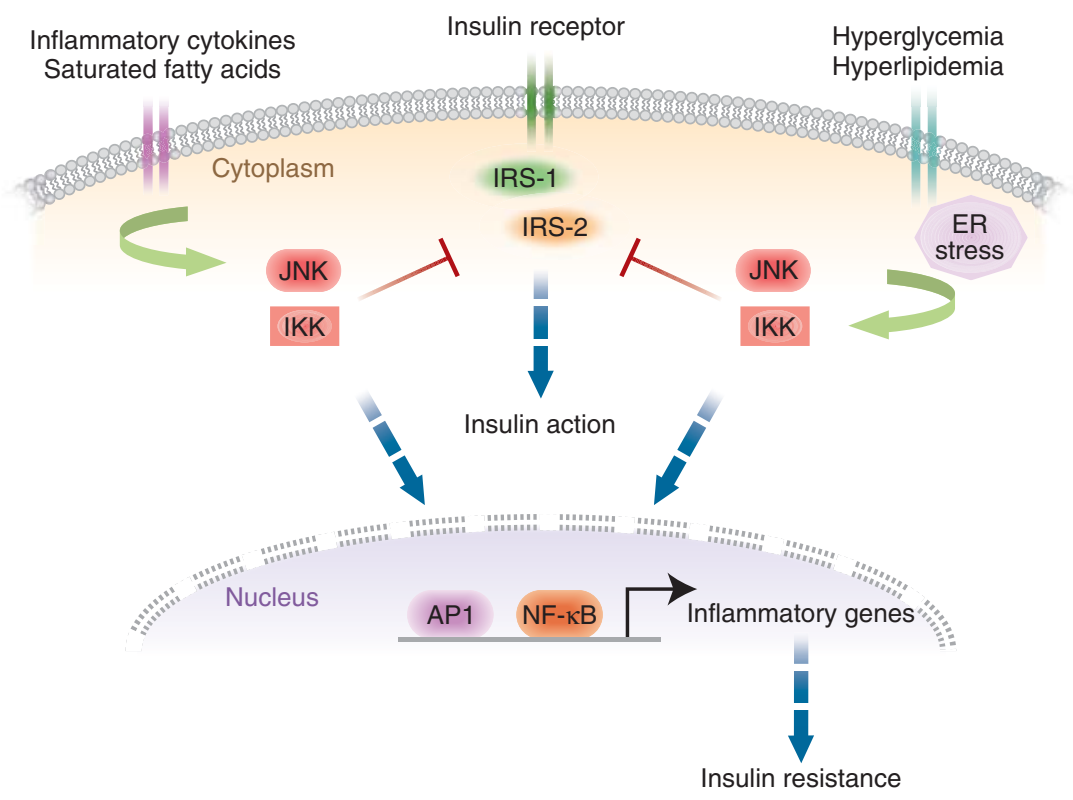

Figure 2. Stress kinases mediate insulin resistance. Anabolic actions of insulin are mediated via the insulin receptor, which becomes autophosphorylated following binding to insulin. This allows for docking and tyrosine phosphorylation of insulin receptor substrate (IRS) proteins, which subsequently activate the downstream insulin signaling pathways. On the other hand, serine phosphorylation of IRS-1 and IRS-2 by stress-activated kinases JNK1 and IKK $\beta$ potently inhibits insulin signaling, resulting in cellular insulin resistance. Moreover, transcriptional activation of inflammatory genes by AP-1 and NF- $\kappa \mathrm{B}$, the transcription factors activated by the stress kinases, promotes insulin resistance in an autocrine and paracrine manner in metabolic tissues. In obesity, the increased influx of glucose and free fatty acids and production of ROS induces ER stress, resulting in activation of JNK signaling, whereas obesity-induced inflammation activates JNK and IKK $\beta$ signaling to promote insulin resistance. (This figure is from Odegaard and Chawla 2011; reprinted, with express permission, from the authors.)

resistance as a bona fide inflammatory disorder. Insulin resistance has been associated with elevated serum levels of pro-inflammatory cytokines (e.g., IL-1 $\beta$, IL-6, IL-8, IL-12, and TNF $\alpha$ ), chemokines (e.g., MCP-1, RANTES, and MIP-1), acute phase reactants (e.g., Creactive protein, serum amyloid $\mathrm{A}$, and ferritin), and insulin resistance-associated adipokines (e.g., retinol binding protein-4 and resistin), as well as with decreased serum levels of the so-called negative acute-phase reactants (e.g., transcortin, and transferrin), insulin sensitivity-associated adipokines (e.g., adiponectin, visfatin, omentin, and vaspin), and Th2-type cytokines (IL-4, IL-10) (Shoelson et al. 2006; Qatanani and Lazar 2007; Olefsky and Glass 2010).

\section{MACROPHAGES IN OBESITY}

Despite this extensive characterization effort, it was not until almost a decade later that the first systematic approaches to characterizing the role of the innate immune activation were published. Profiling studies of visceral fat from lean and obese animals showed that rather than a passive energy repository, adipose tissue teems with hematopoietic cells whose activation states and functionalities vary with the nutritional status of the organism (Hotamisligil 2006). However, despite the presence of T-cells and B-cells, NK cells, DCs, NKT cells, eosinophils, mast cells, and basophils in obese adipose tissue, macrophages are numerically and functionally dominant. Macrophages comprise $\sim 10 \%-15 \%$ of 
all cells within lean visceral adipose tissue and expand tremendously with obesity, where they account for a staggering $45 \%-60 \%$ of all cells (Weisberg et al. 2003; Xu et al. 2003). Importantly, this numerical expansion is accompanied by a marked phenotypic transition as well: adipose tissue-associated macrophages isolated from lean animals express a distinct bias toward alternative activation, which is swapped for a pro-inflammatory classical bent with the acquisition of obesity (Lumeng et al. 2007a; Odegaard et al. 2007). Similarly, liver-associated macrophages-Kupffer cells-isolated from lean animals are markedly alternatively biased, whereas those from obese animals are polarized in the opposite direction of classical activation (Odegaard et al. 2008). To appreciate the significance of this transition, we must first briefly discuss the physiological implications of the classical and alternative activation phenotypes.

\section{Macrophage Activation}

Macrophages, in their canonical role as sentinels of the innate immune system, are responsible for sensing, integrating, and responding appropriately to myriad stimuli in their tissue milieux. Despite the protean nature of these stimuli, macrophage activity is channeled through two distinct response patterns designated as classical (M1) and alternative (M2) activation (Gordon 2003). These programs constitute the stereotyped response to bacterial and parasitic infection, respectively: Classical activation results in short-lived, highly inflammatory macrophages with potent bactericidal potential, whereas alternative activation is associated with enduring anti-parasitic and regulatory/reparative responses (Martinez et al. 2009; Odegaard and Chawla 2011). Classically activated macrophages secrete large amounts of pro-inflammatory cytokines (e.g., IL-1 $\beta$, IL-6, IL-8, IL-12, $\mathrm{TNF} \alpha$ ), express high levels of costimulatory molecules important in T-cell activation (e.g., MHC, CD40, CD86), and produce bactericidal mediators, such as nitric oxide, via Nos2 (Gordon 2003). Conversely, alternatively activated cells have a distinct secretory phenotype (e.g.,
IL-10, TGF $\beta$, Chi313, Retnla), express numerous pattern recognition receptors (e.g., mannose receptor, dectin, CD301), and metabolize arginine to produce biosynthetic precursors (e.g., polyamines, proline) via arginase 1 (Martinez et al. 2009; Odegaard and Chawla 2011).

Although these activation state definitions rest on the macrophage's role in host defense, further study has defined their critical function in non-immunological contexts as well. For example, the classical phenotype is implicated in numerous inflammatory and metabolic diseases, whereas alternative activation is associated with wound healing, tissue remodeling, metabolic homeostasis, and atopic disease (Gordon 2003; Odegaard and Chawla 2011). Although the classical-alternative dichotomy has been studied in numerous contexts, few instances are as instructive as the tissue-macrophage relationship in metabolic disease.

\section{Adipose Tissue Macrophages, Inflammation,} and Insulin Resistance

Aside from the observational data presented above, at least four distinct lines of evidence implicate the macrophage as the nexus of inflammatory insulin resistance (Fig. 3). First, ablation of $\mathrm{CD}_{11 \mathrm{c}^{+}}$inflammatory macrophages using CD11c-DTR transgenic mice improves insulin sensitivity without altering adipose tissue mass in obese animals (Patsouris et al. 2008). Second, interference with inflammatory macrophage recruitment through genetic or pharmacologic disruption of $\mathrm{C}-\mathrm{C}$ motif chemokine receptor-2 (CCR2) results in protection against obesity-related insulin resistance and hepatic steatosis (Weisberg et al. 2006; Ito et al. 2008). Third, transgenic mice expressing $\mathrm{Ccl} 2$, a ligand for CCR2, in adipocytes have macrophage infiltration of their adipose tissue that is associated with increased insulin resistance (Kamei et al. 2006; Kanda et al. 2006). Lastly, hematopoietic-specific loss of JNK1 and myeloid-specific loss of IKK $\beta$, both interventions that render macrophages inflammatorily effete, preclude the development of obesity-related insulin resistance (Arkan et al. 2005; Solinas et al. 2007). 


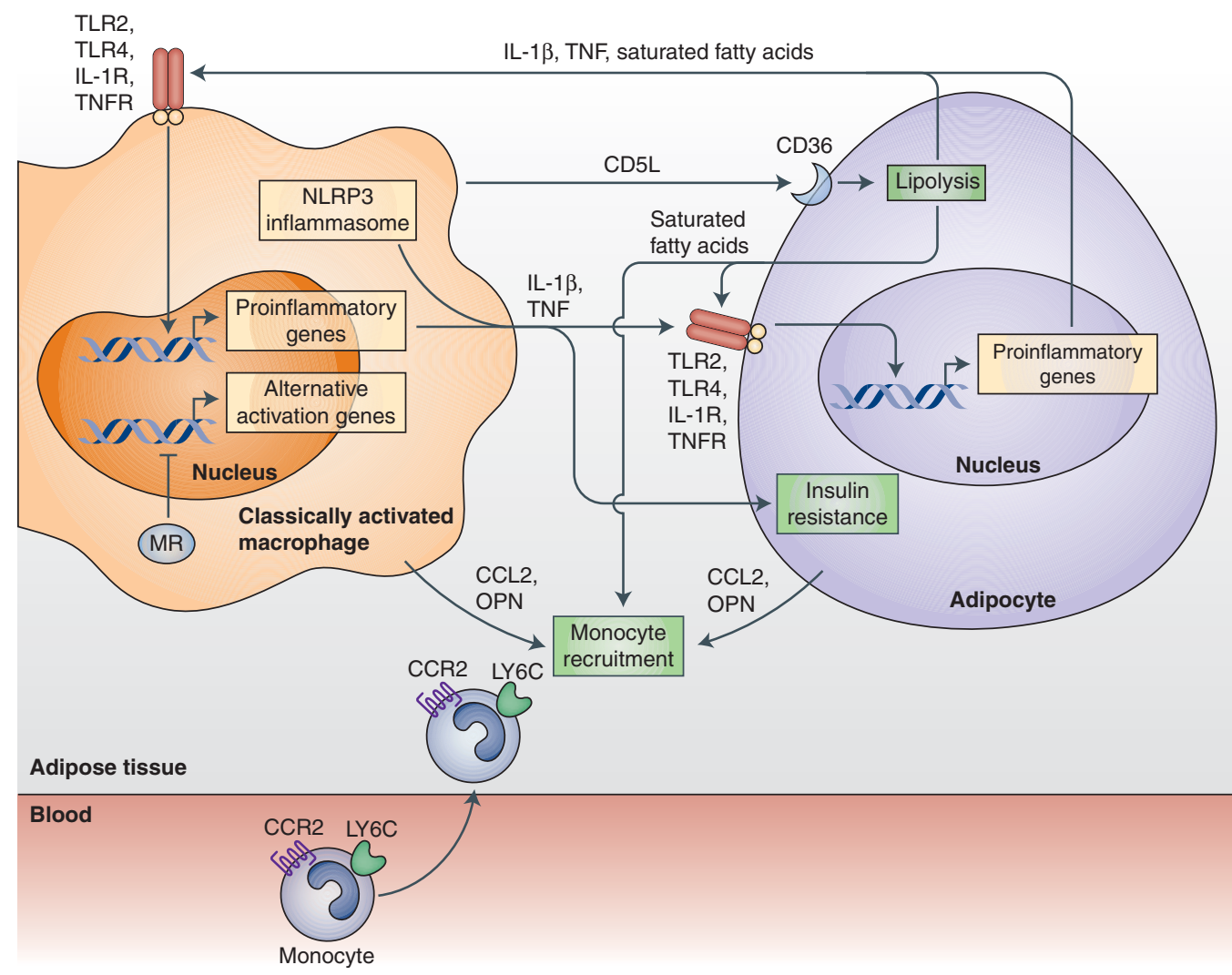

Figure 3. Obesity results in recruitment of macrophages into adipose tissue, which promotes adipose tissue inflammation and insulin resistance. Obesity results in increased levels of circulating saturated fatty acids, which activate Toll-like receptors $2 / 4$ (TLR2/4) to promote classical activation of adipose tissue macrophages. Secretion of inflammatory cytokines, such as IL- $1 \beta$ and TNF- $\alpha$, by adipose tissue macrophages inhibits insulin action in adipocytes. Moreover, activation of the NLRP3-containing inflammasomes, potentially by ceramides, augments the release IL- $1 \beta$ by classically activated macrophages. Cross talk between adipocytes and adipose tissue macrophages perpetuates these inflammatory cascades via release of chemokines, cytokines, and fatty acids. Ccl2 and osteopontin $(\mathrm{OPN})$ are two chemoattractants implicated in the recruitment of Ly6C ${ }^{+} \mathrm{CCR} 2^{+}$inflammatory monocytes, which differentiate into classically activated adipose tissue macrophages. CD5-like antigen (CD5L), a peptide released by macrophages that is incorporated into adipocytes via CD36-mediated endocytosis, potentiates lipolysis of triglycerides in adipocytes. This establishes a feed-forward loop in which the released fatty acids induce chemokine expression, potentiating monocyte and macrophage recruitment into adipose tissue. By inhibiting the IL-4- and PPAR $\gamma$-driven program of alternative activation, mineralocorticoid (MR) signaling contributes to classical activation of adipose tissue macrophages. (This figure is from Chawla et al. 2011; reprinted, with express permission, from the author.)

\section{Triggers for Classical Activation}

Several lines of evidence link well-described events early in obesity with classical macrophage activation. Obesity is characterized by the expansion of adipose tissue: Adipose tissue depots expand approximately fivefold to 10 fold over their lean mass. This massive hypertrophy induces necrosis of adipocytes due to excessive ER stress and hypoxia, as the expanding tissue outgrows its vascular supply (Hotamisligil 2006; Rutkowski et al. 2009), providing a potent inflammatory stimuli for macrophages (Savill and Fadok 2000; Savill et al. 2002). Indeed, 
temporal analyses of obesity reveal a correlation between the appearance of necrotic adipocytes surrounded by inflammatory CD11c ${ }^{+}$macrophages and the onset of clinical insulin resistance (Cinti et al. 2005; Strissel et al. 2007).

Another hallmark of developing obesity is dysregulation of fatty acid homeostasis, which is usually associated with high-risk dietary patterns (e.g., refined sugars and saturated fatty acid consumption). Interestingly, the same saturated fatty acids that come to dominate the obese lipid milieu are capable of activating Toll-like receptor 4 (TLR4), a sensor evolutionarily tuned to structurally similar bacterial lipids such as lipopolysaccharide, to produce an inflammatory response (Konner and Bruning 2011). Indeed, infusion of saturated fatty acids alone is sufficient to induce acute insulin resistance in the absence of obesity (Shi et al. 2006), whereas genetic deletion of TLR4 in experimental animals protects against diet-induced insulin resistance (Saberi et al. 2009). Accompanying this shift in fatty acid composition, escalating ceramide biosynthesis also contributes to inflammatory activation (Vandanmagsar et al. 2011).

\section{Inflammasome Activation}

Many inflammatory signaling cascades, including those provoked by ER stress, hypoxia, necrotic cellular debris, and ceramide dysregulation, converge on the inflammasome, a multiprotein complex critical for the production and secretion of IL-1 $\beta$ and IL-18 (Petrilli et al. 2007; Chen and Nunez 2010). Indeed, adipose tissue inflammasome activation, both in adipocytes and macrophages, parallels the development of obesity, resulting in IL-1 $\beta$-mediated inflammatory insulin resistance, whereas its inhibition is effective in control of obesity-related metabolic pathology (Stienstra et al. 2010; Zhou et al. 2010; Vandanmagsar et al. 2011). Interestingly, as obesity progresses and peripheral insulin resistance builds, inflammasome activation is also demonstrable within islet-infiltrating macrophages and the $\beta$-cell itself and is correlated with IL-1 $\beta$ production (Boni-Schnetzler et al. 2008; Maedler et al. 2008; Masters et al.
2010). In keeping with this, treatment of type 2 diabetic patients with anakinra, a competitive IL-1R antagonist, decreases markers of systemic inflammation and improves glycemic control and secretory function of the $\beta$-cells (Larsen et al. 2007).

\section{Macrophage Recruitment}

In addition to the acquisition of an inflammatory phenotype, obesity is also accompanied by a marked increase in macrophage representation, which, in the context of increasing adipose tissue mass, represents de novo recruitment (Weisberg et al. 2003). Among the recruitment factors, CCL2-mediated ingress of Ly6C ${ }^{\text {hi }}$ CCR2 ${ }^{+}$ monocytes, which selectively differentiate into classically activated macrophages, plays a dominant role in trafficking of adipose tissue macrophages (Kamei et al. 2006; Kanda et al. 2006; Weisberg et al. 2006). Congruent with this view, disruption of either CCL2 or CCR2, as mentioned previously, protects against diet-related insulin resistance (Fig. 3).

\section{ISLET INFLAMMATION AND MACROPHAGES}

Emerging data suggest that the macrophage's diabetogenic role extends into the islet itself in a manner strikingly similar to that observed in the adipose tissue. For instance, both adipose tissue and islets isolated from both type 1 and type 2 diabetics are characterized by abnormally high macrophage representation in human subjects and animal models (Hutchings et al. 1990; Ehses et al. 2007; Ferrante 2007; Uno et al. 2007; Richardson et al. 2009). In both instances, this macrophage infiltration parallels the development of peripheral insulin resistance and precedes the emergence of islet-specific immune responses (Dahlen et al. 1998). Furthermore, increasing macrophage representation within these tissues is correlated with the expression of classical activation markers including IL- $1 \beta$ and TNF $\alpha$, which abrogate insulin secretion and signaling in the islet and peripheral tissues, respectively (Arnush et al. 1998; Dahlen et al. 1998; Weisberg et al. 2003; Lumeng et al. 2007b). Accordingly, 
inhibition of macrophage recruitment effectively blunts development and progression of type 1 and type 2 diabetes (Hutchings et al. 1990; Weisberg et al. 2006).

\section{ADAPTIVE IMMUNITY AND INSULIN RESISTANCE}

Although the macrophage is the dominant effector of metabolic inflammation, supporting roles have been ascribed to other innate immune lineages, such as mast cells (Liu et al. 2009), as well as to the adaptive immune system. Interestingly, T-cell and B-cell involvement in peripheral insulin resistance follows a temporal course parallel to that which occurs in the islet during developing autoimmune $\beta$-cell destruction. As obesity-related insulin resistance develops, adipocyte cell death and innate immune activation provide antigenic stimuli similar to those derived from the inflamed islet (Fig. 4). Specifically, obesity-related insulin resistance is accompanied by a phenotypic shift from tolerogenic regulatory $\mathrm{T}$-cells to pro-inflammatory $\mathrm{CD} 4^{+} \mathrm{T}_{\mathrm{H}} 1$ cells that contribute to the phlogistic milieu primarily through production of IFN $\gamma$ (Feuerer et al. 2009; Winer et al. 2009). Similar to the islet, these cells express a limited T-cell receptor (TCR) repertoire, suggesting antigenspecific clonal expansion, although no bona fide autoreactive T-cells have yet been shown (Winer et al. 2009). Moreover, CD ${ }^{+}$T-cells, although not demonstrably cytolytic in this context, accumulate in inflamed adipose tissue, contribute to local inflammation, and are capable of exacerbating existing disease (Nishimura et al. 2009). Interestingly, T-cell depletion in obese mice by anti-CD3 immunotherapy resulted in sustained improvements in insulin resistance without significant alteration in weight (Winer et al. 2009), similar to its effect in the islet in diabetic mice (Chatenoud 1994, 2010; Chatenoud et al. 1994, 1997).

In parallel with T-cells, B2 lymphocytes accumulate in the adipose tissue of obese individuals and mice, leading to increased local and systemic IgG2c levels (Fig. 4) (Winer et al. 2011). Remarkably, transfer of serum IgG but not IgM from obese mice is sufficient to induce insulin resistance in naive, B-cell-deficient animals (Winer et al. 2011). Indeed, serologic profiling of human subjects revealed significantly higher levels of antibodies targeting intracellular antigens in diabetic individuals relative to healthy controls. Congruent with these observations, B-cell depletion through anti-CD20 immunotherapy ameliorates metabolic disease (Winer et al. 2011), similar to those results observed clinically in type 1 diabetics (Pescovitz et al. 2009).

\section{ALTERNATIVELY ACTIVATED MACROPHAGES AND INSULIN SENSITIVITY}

Although much of the last two decades have been spent maligning the role of innate immunity in metabolic homeostasis, evidence of a positive influence is also emerging. The foremost example of innate immunity's beneficent potential is found in the tissue macrophage. In our rush to demonize this cell for its central role in insulin resistance, we neglect the key observation that the adipose tissue and liver of lean, insulin-sensitive individuals are rife with macrophages— 10\%-15\% of all healthy liver and adipose tissue cells are macrophages (Gordon et al. 1992; Weisberg et al. 2003; Lumeng et al. 2007a). Adipose tissue macrophages from lean adipose tissue, rather than being simply not inflammatory, are significantly activated along the alternative pathway (Lumeng et al. 2007a; Odegaard et al. 2007). Similarly, Kupffer cells from lean animals express markers of alternative activation, which they swap for an inflammatory profile in obesity (Odegaard et al. 2008). This hitherto unexpected activationstate diversity raises an important question: What are large numbers of alternatively activated macrophages doing in non-inflamed liver and fat?

\section{Transcriptional Regulation of Alternative Macrophage Activation}

The first experiments addressing this question were derived from early studies of transcriptional determinants of macrophage alternative activation (Fig. 5). These studies showed that 


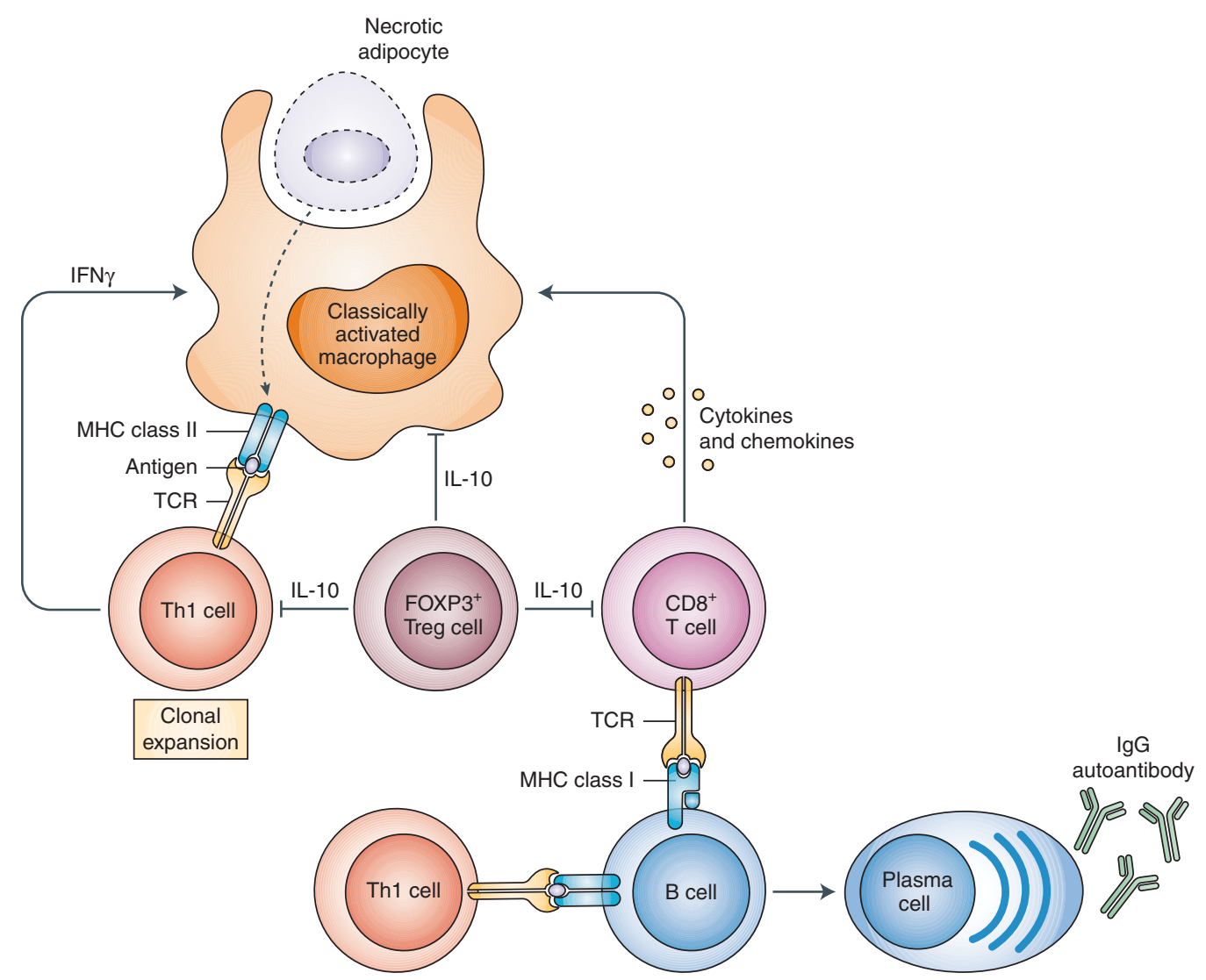

Figure 4. Cross talk between innate and adaptive immune cells in obese adipose tissue. Overnutrition results in necrotic death of engorged adipocytes, resulting in recruitment of classically activated macrophages to clear cellular debris. These classically activated macrophages, which express molecules associated with antigenpresenting cells (MHC class II, CD1d, costimulatory molecules, and CD11c), are potentially capable of presenting necrotic cell-derived antigens to T-cells and B-cells. This will activate adaptive immunity, resulting in clonal expansion of $\mathrm{CD} 4^{+} \mathrm{Th} 1$ cells and recruitment of CD ${ }^{+} \mathrm{T}$-cells. Secretion of chemotactic factors by $\mathrm{CD} 8^{+} \mathrm{T}$-cells and IFN $\gamma$ by $\mathrm{CD} 4^{+}$Th1 cells increases recruitment and classical activation of adipose tissue macrophages, respectively, thereby establishing a vicious cycle of inflammation. The concomitant reduction in numbers of immunosuppressive Treg cells contributes to the adipose tissue inflammation and insulin resistance. Lastly, B-cells, which are capable of presenting antigens to naive T-cells, infiltrate obese adipose tissue and secrete IgG2c antibodies, factors that worsen insulin resistance. (This figure is from Chawla et al. 2011; reprinted, with express permission, from the author.)

although STAT6 was the dominant transcriptional initiator of alternative activation, peroxisome proliferator-activated receptors PPAR $\gamma$ and PPAR $\delta$ - nuclear receptors hitherto recognized only as the body's fatty acid sensorswere identified as critical for sustaining the response (Odegaard et al. 2007, 2008; Kang et al. 2008). In the absence of PPAR $\gamma$, murine macrophages are incapable of affecting the met- abolic shift required for sustained alternative response (Vats et al. 2006; Odegaard et al. 2007), whereas PPAR $\delta$ deficiency disrupts the macrophage's ability to coordinate and sustain the immunologic phenotype of alternative activation (Kang et al. 2008; Odegaard et al. 2008). Either's absence is then sufficient to abrogate any durable alternative response in vitro. In vivo, however, a surprising phenotypical nuance was 
J.I. Odegaard and A. Chawla

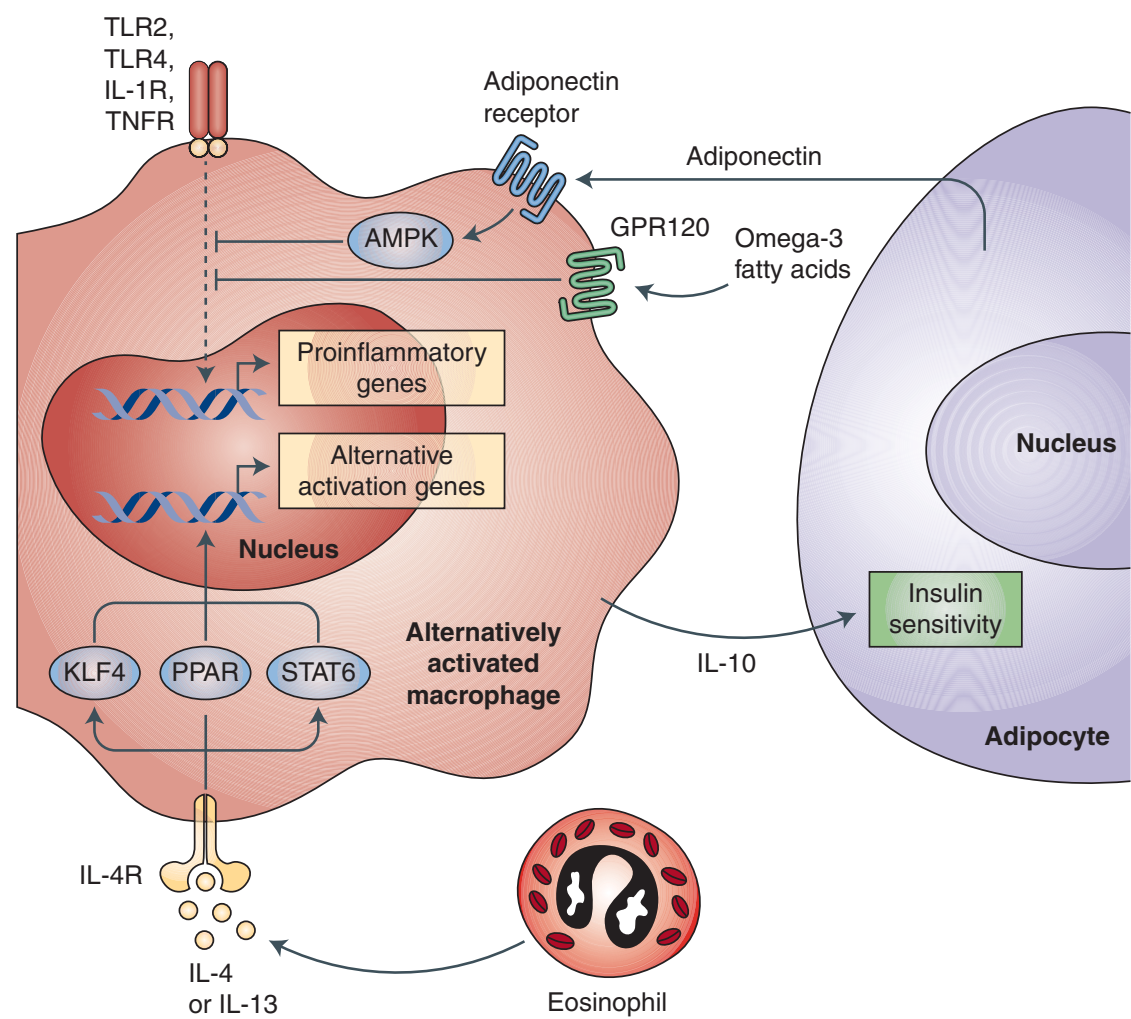

Figure 5. Amelioration of obesity-induced insulin resistance by alternatively activated macrophages. Adipose tissue of lean animals is populated by alternatively activated macrophages, which promote insulin sensitivity in adipocytes by attenuating inflammation and releasing IL-10. Production of IL-4 and IL-13 by eosinophils sustains alternative macrophage activation of adipose tissue macrophages, which can be distinguished by their expression of alternative activation markers CD206, CD301, and Arg1. Transcriptional synergy between STAT6, peroxisome proliferator-activated receptors $\delta / \gamma(\operatorname{PPAR} \delta / \gamma)$, and Krupple-like factor 4 (KLF4) sustains alternative activation of adipose tissue macrophages. Factors derived from lean adipose tissue, such as adiponectin and unsaturated $\omega 3$-fatty acids, synergize with IL-4 signaling to enhance alternative activation and dampen NF-кB-driven classical activation of adipose tissue macrophages. (This figure is from Chawla et al. 2011; reprinted, with express permission, from the author.)

uncovered: macrophage-specific PPAR $\gamma$ deficiency preferentially abolishes alternative activation in visceral adipose tissue macrophages, but loss of PPAR $\delta$ in the hematopoietic system appears to more potently affect Kupffer cell alternative activation capacity (Kang et al. 2008; Odegaard et al. 2008). Importantly, both strains of mice show similar and marked decreases in insulin sensitivity and increased weight gain when challenged with a high-fat diet (Hevener et al. 2007; Odegaard et al. 2007, 2008; Kang et al. 2008), showing that the absence of alternatively activated macrophages impairs insulin signaling even in the absence of established inflammation.

Subsequent mouse models with genetically distinct impairments in macrophage alternative activation (e.g., KLF4-deficient mice) have shown similar phenotypes (Liao et al. 2011), whereas augmentation of the alternative response (e.g., through impaired mineralocorticoid receptor function) has the converse effect (Guo et al. 2008; McManus et al. 2008; Usher et al. 2010). Congruent with these findings, wholesale ablation of Kupffer cells in lean mice results in a similar insulin-resistant phenotype despite a 
reduction in inflammation (Clementi et al. 2009; Huang et al. 2010). Further studies have since shown insulin sensitivity-promoting roles for the alternative macrophage in restraining diabetogenic lymphocytes (Winer et al. 2009), remodeling adipose tissue (Gordon 2003; Martinez et al. 2009), and the immunologically silent disposal of apoptotic cells (Mukundan et al. 2009).

\section{Eosinophils: IL-4-Producing Cells in Adipose Tissue}

The unexpected, Janus-like ability of macrophages to promote insulin sensitivity as well as resistance established a paradigm under which other immunological determinants of insulin sensitivity were actively sought. To this end, differential profiling of other hematopoietic subsets in adipose tissue from lean and obese animals uncovered a striking correlation between eosinophil representation, alternative macrophage activation in adipose tissue, and the obesity-insulin resistance disease axis (Fig. 5). Indeed, eosinophil number shows a tight correlation to macrophage activation status and is inversely related to body mass, insulin resistance, and inflammatory markers (Wu et al. 2011). Furthermore, eosinophil-deficient mice show an alarming propensity to insulin resistance, whereas those with a surfeit of eosinophils (e.g., the IL-5 transgenic mouse) are resistant to diet-induced obesity and insulin resistance (Wu et al. 2011).

\section{CONCLUSION}

The diabetogenic environment has changed dramatically in recent decades such that our traditional dualistic concept of type 1 and type 2 diabetes is no longer operable. Rather, obesity, inactivity, dietary indiscretion, and other environmental trappings of the modern world have positioned inflammatory insulin resistance as the driving factor across the diabetic spectrum (Fig. 1). Indeed, perhaps the most common presentation of type 1 diabetes is now in a young type 2 diabetic.
Recognition of inflammation-induced insulin resistance as a primary etiologic determinant across the modern diabetes landscape has important therapeutic implications. Indeed, as we have discussed above, therapeutic approaches originally limited to type 2 diabetes-for example, weight loss, exercise, and insulin-sensitizing agents-have shown remarkable efficacy in preventing/slowing type 1 disease as well (Kjems et al. 2003; Miller and Silverstein 2006; Kilpatrick et al. 2007; Moon et al. 2007; Neovius et al. 2008; Pozzilli and Guglielmi 2009), confirming the validity of integrated diabetes therapy. With these approaches, therapies have begun not only to stave off relentless $\beta$-cell destruction but, for the first time, to actually rebuild $\beta$-cell mass by tapping the inherent regenerative capacity of $\beta$-cells (Meier et al. 2005). One salient example of such a resurrection therapy is the IL-1 $\beta$-targeted therapeutics (Fig. 1). This class of agents-typified by anakinra, a competitive IL-1R antagonist-has shown remarkable promise in both type 1 and type 2 disease. As mentioned above, IL-1 $\beta$ - a pro-inflammatory mediator produced in spades in inflammatory insulin resistance-potently inhibits insulin secretion and induces $\beta$-cell apoptosis (Poitout and Robertson 2008) in addition to directly inhibiting insulin activity in the periphery (Yuan et al. 2001; Hirosumi et al. 2002; Arkan et al. 2005; Cai et al. 2005). Congruent with these observations, overexpression or exogenous administration of the naturally occurring inhibitor of IL-1 $\beta$ signaling, IL-1R antagonist (IL-1Ra), has shown potent therapeutic effect in animal models and pilot studies (Osborn et al. 2008; Sauter et al. 2008; Owyang et al. 2010) where, remarkably, these interventions not only halted disease progression but actually reversed $\beta$-cell loss (Tellez et al. 2005), showing that even a battered reserve of $\beta$-cells is sufficient to repopulate the islet. Indeed, a recent clinical trial confirmed the therapeutic efficacy of IL$1 \mathrm{R}$ antagonism in established type 2 diabetics (Larsen et al. 2007) and provided practical justification for similar efforts in progress in type 1 disease (Mandrup-Poulsen et al. 2010).

The efficacy of these integrated, innate immunity-targeted therapeutic approaches-in 
addition to providing desperately needed therapeutic options - underscores the importance of inflammatory insulin resistance across the diabetic spectrum and reiterates the continued role of innate immunity in human health and disease.

\section{ACKNOWLEDGMENTS}

Our work is supported by grants from the NIH (DK076760, HL076746), Larry L. Hillblom Foundation Network Grant, Diabetes Family Fund (UCSF), and an NIH Director's Pioneer Award (DP1OD006415) to A.C. Because of space limitations, we regret that we are unable to cite all relevant publications on this topic from our colleagues.

\section{REFERENCES}

Arkan MC, Hevener AL, Greten FR, Maeda S, Li ZW, Long JM, Wynshaw-Boris A, Poli G, Olefsky J, Karin M. 2005. IKK- $\beta$ links inflammation to obesity-induced insulin resistance. Nat Med 11: 191-198.

Arnush M, Scarim AL, Heitmeier MR, Kelly CB, Corbett JA. 1998. Potential role of resident islet macrophage activation in the initiation of autoimmune diabetes. J Immunol 160: $2684-2691$

Baum JD, Ounsted M, Smith MA. 1975. Letter: Weight gain in infancy and subsequent development of diabetes mellitus in childhood. Lancet 2: 866.

Betts P, Mulligan J, Ward P, Smith B, Wilkin T. 2005. Increasing body weight predicts the earlier onset of insulindependant diabetes in childhood: Testing the "accelerator hypothesis" (2). Diabet Med 22: 144-151.

Boni-Schnetzler M, Thorne J, Parnaud G, Marselli L, Ehses JA, Kerr-Conte J, Pattou F, Halban PA, Weir GC, Donath MY. 2008. Increased interleukin (IL)-1 $\beta$ messenger ribonucleic acid expression in $\beta$-cells of individuals with type 2 diabetes and regulation of IL- $1 \beta$ in human islets by glucose and autostimulation. J Clin Endocrinol Metab 93: 4065-4074.

Boni-Schnetzler M, Boller S, Debray S, Bouzakri K, Meier DT, Prazak R, Kerr-Conte J, Pattou F, Ehses JA, Schuit FC, et al. 2009. Free fatty acids induce a proinflammatory response in islets via the abundantly expressed interleukin-1 receptor I. Endocrinology 150: 5218-5229.

Brown MS, Goldstein JL. 2008. Selective versus total insulin resistance: A pathogenic paradox. Cell Metab 7: 95-96.

Bruining GJ, Netherlands Kolibrie Study Group of Childhood Diabetes. 2000. Association between infant growth before onset of juvenile type-1 diabetes and autoantibodies to IA-2. Lancet 356: 655-656.

Cai D, Yuan M, Frantz DF, Melendez PA, Hansen L, Lee J, Shoelson SE. 2005. Local and systemic insulin resistance resulting from hepatic activation of IKK- $\beta$ and NF-кB. Nat Med 11: 183-190.
Chatenoud L. 1994. Use of CD3 antibodies in transplantation and autoimmune diseases. Transplant Proc 26:3191-3193.

Chatenoud L. 2010. Immune therapy for type 1 diabetes mellitus-what is unique about anti-CD3 antibodies? Nat Rev Endocrinol 6: 149-157.

Chatenoud L, Thervet E, Primo J, Bach JF. 1994. Anti-CD3 antibody induces long-term remission of overt autoimmunity in nonobese diabetic mice. Proc Natl Acad Sci 91: 123-127.

Chatenoud L, Primo J, Bach JF. 1997. CD3 antibody-induced dominant self tolerance in overtly diabetic NOD mice. J Immunol 158: 2947-2954.

Chawla A, Nguyen KD, Goh YP. 2011. Macrophage-mediated inflammation in metabolic disease. Nat Rev Immunol 11: 738-749.

Chen GY, Nunez G. 2010. Sterile inflammation: Sensing and reacting to damage. Nat Rev Immunol 10: 826-837.

Cinti S, Mitchell G, Barbatelli G, Murano I, Ceresi E, Faloia E, Wang S, Fortier M, Greenberg AS, Obin MS. 2005. Adipocyte death defines macrophage localization and function in adipose tissue of obese mice and humans. J Lipid Res 46: 2347-2355.

Clementi AH, Gaudy AM, van Rooijen N, Pierce RH, Mooney RA. 2009. Loss of Kupffer cells in diet-induced obesity is associated with increased hepatic steatosis, STAT3 signaling, and further decreases in insulin signaling. Biochim Biophys Acta 1792: 1062-1072.

Dabelea D, D'Agostino RB Jr, Mayer-Davis EJ, Pettitt DJ, Imperatore G, Dolan LM, Pihoker C, Hillier TA, Marcovina SM, Linder B, et al. 2006. Testing the accelerator hypothesis: Body size, $\beta$-cell function, and age at onset of type 1 (autoimmune) diabetes. Diabetes Care 29: 290294.

Dahlen E, Dawe K, Ohlsson L, Hedlund G. 1998. Dendritic cells and macrophages are the first and major producers of TNF- $\alpha$ in pancreatic islets in the nonobese diabetic mouse. J Immunol 160: 3585-3593.

Ehses JA, Perren A, Eppler E, Ribaux P, Pospisilik JA, MaorCahn R, Gueripel X, Ellingsgaard H, Schneider MK, Biollaz G, et al. 2007. Increased number of islet-associated macrophages in type 2 diabetes. Diabetes 56: 2356-2370.

Eizirik DL. 1988. Interleukin-1 induced impairment in pancreatic islet oxidative metabolism of glucose is potentiated by tumor necrosis factor. Acta Endocrinol (Copenh) 119: $321-325$.

Elouil H, Cardozo AK, Eizirik DL, Henquin JC, Jonas JC. 2005. High glucose and hydrogen peroxide increase $\mathrm{c}-\mathrm{Myc}$ and haeme-oxygenase $1 \mathrm{mRNA}$ levels in rat pancreatic islets without activating NFкB. Diabetologia 48: 496-505.

Ferrante AW Jr. 2007. Obesity-induced inflammation: A metabolic dialogue in the language of inflammation. J Intern Med 262: 408-414.

Feuerer M, Herrero L, Cipolletta D, Naaz A, Wong J, Nayer A, Lee J, Goldfine AB, Benoist C, Shoelson S, et al. 2009. Lean, but not obese, fat is enriched for a unique population of regulatory $\mathrm{T}$ cells that affect metabolic parameters. Nat Med 15: 930-939.

Flegal KM, Carroll MD, Ogden CL, Curtin LR. 2010. Prevalence and trends in obesity among US adults, 19992008. JAMA 303: 235-241. 
Fourlanos S, Harrison LC, Colman PG. 2008a. The accelerator hypothesis and increasing incidence of type 1 diabetes. Curr Opin Endocrinol Diabetes Obes 15: 321-325.

Fourlanos S, Varney MD, Tait BD, Morahan G, Honeyman MC, Colman PG, Harrison LC. 2008b. The rising incidence of type 1 diabetes is accounted for by cases with lower-risk human leukocyte antigen genotypes. Diabetes Care 31: 1546-1549.

Gordon S. 2003. Alternative activation of macrophages. Nat Rev Immunol 3: 23-35.

Gordon S, Fraser I, Nath D, Hughes D, Clarke S. 1992. Macrophages in tissues and in vitro. Curr Opin Immunol 4: $25-32$.

Guo C, Ricchiuti V, Lian BQ, Yao TM, Coutinho P, Romero JR, Li J, Williams GH, Adler GK. 2008. Mineralocorticoid receptor blockade reverses obesity-related changes in expression of adiponectin, peroxisome proliferator-activated receptor- $\gamma$, and proinflammatory adipokines. Circulation 117: 2253-2261.

Harding HP, Ron D. 2002. Endoplasmic reticulum stress and the development of diabetes: A review. Diabetes 51 (Suppl 3): S455-S461.

Hevener AL, Olefsky JM, Reichart D, Nguyen MT, Bandyopadyhay G, Leung HY, Watt MJ, Benner C, Febbraio MA, Nguyen AK, et al. 2007. Macrophage PPAR $\gamma$ is required for normal skeletal muscle and hepatic insulin sensitivity and full antidiabetic effects of thiazolidinediones. J Clin Invest 117: 1658-1669.

Himsworth HP. 1939. The mechanism of diabetes mellitus. Lancet 234: 171-176.

Hirosumi J, Tuncman G, Chang L, Gorgun CZ, Uysal KT, Maeda K, Karin M, Hotamisligil GS. 2002. A central role for JNK in obesity and insulin resistance. Nature 420: $333-336$

Hotamisligil GS. 2003. Inflammatory pathways and insulin action. Int J Obes Relat Metab Disord 27 (Suppl 3): S53S55.

Hotamisligil GS. 2006. Inflammation and metabolic disorders. Nature 444: 860-867.

Hotamisligil GS. 2010. Endoplasmic reticulum stress and the inflammatory basis of metabolic disease. Cell 140: 900-917.

Hotamisligil GS, Shargill NS, Spiegelman BM. 1993. Adipose expression of tumor necrosis factor- $\alpha$ : Direct role in obesity-linked insulin resistance. Science 259: 87-91.

Hotamisligil GS, Peraldi P, Budavari A, Ellis R, White MF, Spiegelman BM. 1996. IRS-1-mediated inhibition of insulin receptor tyrosine kinase activity in TNF- $\alpha$ - and obesity-induced insulin resistance. Science 271: 665-668.

Huang W, Metlakunta A, Dedousis N, Zhang P, Sipula I, Dube JJ, Scott DK, O'Doherty RM. 2010. Depletion of liver Kupffer cells prevents the development of diet-induced hepatic steatosis and insulin resistance. Diabetes 59: $347-357$.

Hutchings P, Rosen H, O'Reilly L, Simpson E, Gordon S, Cooke A. 1990. Transfer of diabetes in mice prevented by blockade of adhesion-promoting receptor on macrophages. Nature 348: 639-642.

Hypponen E, Kenward MG, Virtanen SM, Piitulainen A, Virta-Autio P, Tuomilehto J, Knip M, Akerblom HK Childhood Diabetes in Finland (DiMe) Study Group.
1999. Infant feeding, early weight gain, and risk of type 1 diabetes. Diabetes Care 22: 1961-1965.

Hypponen E, Virtanen SM, Kenward MG, Knip M, Akerblom HK. 2000. Obesity, increased linear growth, and risk of type 1 diabetes in children. Diabetes Care 23: $1755-1760$.

Ito A, Suganami T, Yamauchi A, Degawa-Yamauchi M, Tanaka M, Kouyama R, Kobayashi Y, Nitta N, Yasuda K, Hirata Y, et al. 2008. Role of CC chemokine receptor 2 in bone marrow cells in the recruitment of macrophages into obese adipose tissue. J Biol Chem 283: 35715-35723.

Johansson C, Samuelsson U, Ludvigsson J. 1994. A high weight gain early in life is associated with an increased risk of type 1 (insulin-dependent) diabetes mellitus. $D i$ abetologia 37: 91-94.

Kahn BB, Flier JS. 2000. Obesity and insulin resistance. $J$ Clin Invest 106: 473-481.

Kamei N, Tobe K, Suzuki R, Ohsugi M, Watanabe T, Kubota N, Ohtsuka-Kowatari N, Kumagai K, Sakamoto K, Kobayashi M, et al. 2006. Overexpression of monocyte chemoattractant protein- 1 in adipose tissues causes macrophage recruitment and insulin resistance. J Biol Chem 281: 26602-26614.

Kanda H, Tateya S, Tamori Y, Kotani K, Hiasa K, Kitazawa R, Kitazawa S, Miyachi H, Maeda S, Egashira K, et al. 2006. MCP-1 contributes to macrophage infiltration into adipose tissue, insulin resistance, and hepatic steatosis in obesity. J Clin Invest 116: 1494-1505.

Kang K, Reilly SM, Karabacak V, Gangl MR, Fitzgerald K, Hatano B, Lee CH. 2008. Adipocyte-derived Th2 cytokines and myeloid PPAR $\delta$ regulate macrophage polarization and insulin sensitivity. Cell Metab 7: 485-495.

Kibirige M, Metcalf B, Renuka R, Wilkin TJ. 2003. Testing the accelerator hypothesis: The relationship between body mass and age at diagnosis of type 1 diabetes. Diabetes Care 26: 2865-2870.

Kilpatrick ES, Rigby AS, Atkin SL. 2007. Insulin resistance, the metabolic syndrome, and complication risk in type 1 diabetes: "Double diabetes" in the Diabetes Control and Complications Trial. Diabetes Care 30: 707-712.

Kjems LL, Holst JJ, Volund A, Madsbad S. 2003. The influence of GLP-1 on glucose-stimulated insulin secretion: Effects on $\beta$-cell sensitivity in type 2 and nondiabetic subjects. Diabetes 52: 380-386.

Knerr I, Wolf J, Reinehr T, Stachow R, Grabert M, Schober E, Rascher W, Holl RW. 2005. The "accelerator hypothesis": Relationship between weight, height, body mass index and age at diagnosis in a large cohort of 9,248 German and Austrian children with type 1 diabetes mellitus. Diabetologia 48: 2501-2504.

Konner AC, Bruning JC. 2011. Toll-like receptors: Linking inflammation to metabolism. Trends Endocrinol Metab 22: $16-23$

Kordonouri O, Hartmann R. 2005. Higher body weight is associated with earlier onset of Type 1 diabetes in children: Confirming the "Accelerator Hypothesis". Diabet Med 22: 1783-1784.

Larsen CM, Faulenbach M, Vaag A, Volund A, Ehses JA, Seifert B, Mandrup-Poulsen T, Donath MY. 2007. Interleukin-1-receptor antagonist in type 2 diabetes mellitus. $N$ Engl J Med 356: 1517-1526. 
Lee Y, Hirose H, Ohneda M, Johnson JH, McGarry JD, Unger RH. 1994. $\beta$-Cell lipotoxicity in the pathogenesis of non-insulin-dependent diabetes mellitus of obese rats: Impairment in adipocyte- $\beta$-cell relationships. Proc Natl Acad Sci 91: 10878-10882.

Liao X, Sharma N, Kapadia F, Zhou G, Lu Y, Hong H, Paruchuri K, Mahabeleshwar GH, Dalmas E, Venteclef N, et al. 2011. Kruppel-like factor 4 regulates macrophage polarization. J Clin Invest 121: 2736-2749.

Liu J, Divoux A, Sun J, Zhang J, Clement K, Glickman JN, Sukhova GK, Wolters PJ, Du J, Gorgun CZ, et al. 2009. Genetic deficiency and pharmacological stabilization of mast cells reduce diet-induced obesity and diabetes in mice. Nat Med 15: 940-945.

Lumeng CN, Saltiel AR. 2011. Inflammatory links between obesity and metabolic disease. J Clin Invest 121: 2111 2117.

Lumeng CN, Bodzin JL, Saltiel AR. 2007a. Obesity induces a phenotypic switch in adipose tissue macrophage polarization. J Clin Invest 117: 175-184.

Lumeng CN, Deyoung SM, Saltiel AR. 2007b. Macrophages block insulin action in adipocytes by altering expression of signaling and glucose transport proteins. Am J Physiol Endocrinol Metab 292: E166-E174.

Maedler K, Schulthess FT, Bielman C, Berney T, Bonny C, Prentki M, Donath MY, Roduit R. 2008. Glucose and leptin induce apoptosis in human $\beta$-cells and impair glucose-stimulated insulin secretion through activation of c-Jun N-terminal kinases. FASEB J 22: 1905-1913.

Maedler K, Dharmadhikari G, Schumann DM, Storling J. 2011. Interleukin-targeted therapy for metabolic syndrome and type 2 diabetes. Handb Exp Pharmacol 2011: 257-278.

Mandrup-Poulsen T, Bendtzen K, Nielsen JH, Bendixen G, Nerup J. 1985. Cytokines cause functional and structural damage to isolated islets of Langerhans. Allergy 40: 424429.

Mandrup-Poulsen T, Pickersgill L, Donath MY. 2010. Blockade of interleukin 1 in type 1 diabetes mellitus. Nat Rev Endocrinol 6: 158-166.

Martinez FO, Helming L, Gordon S. 2009. Alternative activation of macrophages: An immunologic functional perspective. Annu Rev Immunol 27: 451-483.

Masters SL, Dunne A, Subramanian SL, Hull RL, Tannahill GM, Sharp FA, Becker C, Franchi L, Yoshihara E, Chen Z, et al. 2010. Activation of the NLRP3 inflammasome by islet amyloid polypeptide provides a mechanism for enhanced IL-1 $\beta$ in type 2 diabetes. Nat Immunol 11: 897-904.

McCarthy MI, Hattersley AT. 2008. Learning from molecular genetics: Novel insights arising from the definition of genes for monogenic and type 2 diabetes. Diabetes 57: 2889-2898.

McManus F, McInnes GT, Connell JM. 2008. Drug Insight: Eplerenone, a mineralocorticoid-receptor antagonist. Nat Clin Pract Endocrinol Metab 4: 44-52.

Meier JJ, Bhushan A, Butler AE, Rizza RA, Butler PC. 2005. Sustained $\beta$ cell apoptosis in patients with long-standing type 1 diabetes: Indirect evidence for islet regeneration? Diabetologia 48: 2221-2228.
Miller JL, Silverstein JH. 2006. The treatment of type 2 diabetes mellitus in youth: Which therapies? Treat Endocrinol 5: 201-210.

Mokdad AH, Marks JS, Stroup DF, Gerberding JL. 2004. Actual causes of death in the United States, 2000. JAMA 291: 1238-1245.

Mokdad AH, Marks JS, Stroup DF, Gerberding JL. 2005. Correction: Actual causes of death in the United States, 2000. JAMA 293: 293-294.

Molbak AG, Christau B, Marner B, Borch-Johnsen K, Nerup J. 1994. Incidence of insulin-dependent diabetes mellitus in age groups over 30 years in Denmark. Diabet Med 11: 650-655.

Moon RJ, Bascombe LA, Holt RI. 2007. The addition of metformin in type 1 diabetes improves insulin sensitivity, diabetic control, body composition and patient wellbeing. Diabetes Obes Metab 9: 143-145.

Mukundan L, Odegaard JI, Morel CR, Heredia JE, Mwangi JW, Ricardo-Gonzalez RR, Goh YP, Eagle AR, Dunn SE, Awakuni JU, et al. 2009. PPAR- $\delta$ senses and orchestrates clearance of apoptotic cells to promote tolerance. Nat Med 15: 1266-1272.

Neovius M, Johansson K, Rossner S. 2008. Head-to-head studies evaluating efficacy of pharmaco-therapy for obesity: A systematic review and meta-analysis. Obes Rev 9: 420-427.

Nishimura S, Manabe I, Nagasaki M, Eto K, Yamashita H, Ohsugi M, Otsu M, Hara K, Ueki K, Sugiura S, et al. 2009. CD ${ }^{+}$effector $\mathrm{T}$ cells contribute to macrophage recruitment and adipose tissue inflammation in obesity. Nat Med 15: 914-920.

Odegaard JI, Chawla A. 2008. Mechanisms of macrophage activation in obesity-induced insulin resistance. Nat Clin Pract Endocrinol Metab 4: 619-626.

Odegaard JI, Chawla A. 2011. Alternative macrophage activation and metabolism. Annu Rev Pathol 6: 275-297.

Odegaard JI, Ricardo-Gonzalez RR, Goforth MH, Morel CR, Subramanian V, Mukundan L, Eagle AR, Vats D, Brombacher F, Ferrante AW, et al. 2007. Macrophage-specific PPAR $\gamma$ controls alternative activation and improves insulin resistance. Nature 447: 1116-1120.

Odegaard JI, Ricardo-Gonzalez RR, Red Eagle A, Vats D, Morel CR, Goforth MH, Subramanian V, Mukundan L, Ferrante AW, Chawla A. 2008. Alternative M2 activation of Kupffer cells by PPAR $\delta$ ameliorates obesity-induced insulin resistance. Cell Metab 7: 496-507.

Ogasawara K, Hamerman JA, Ehrlich LR, Bour-Jordan H, Santamaria P, Bluestone JA, Lanier LL. 2004. NKG2D blockade prevents autoimmune diabetes in NOD mice. Immunity 20: 757-767.

Olefsky J, Glass C. 2010. Macrophages, inflammation, and insulin resistance. Annu Rev Physiol 72: 1-28.

Osborn O, Brownell SE, Sanchez-Alavez M, Salomon D, Gram H, Bartfai T. 2008. Treatment with an interleukin $1 \beta$ antibody improves glycemic control in diet-induced obesity. Cytokine 44: 141-148

Owyang AM, Maedler K, Gross L, Yin J, Esposito L, Shu L, Jadhav J, Domsgen E, Bergemann J, Lee S, et al. 2010. XOMA 052, an anti-IL-1 $\beta$ monoclonal antibody, improves glucose control and $\beta$-cell function in the diet-induced obesity mouse model. Endocrinology 151: 25152527. 
Patsouris D, Li PP, Thapar D, Chapman J, Olefsky JM, Neels JG. 2008. Ablation of CD11c-positive cells normalizes insulin sensitivity in obese insulin resistant animals. Cell Metab 8: 301-309.

Patterson CC, Dahlquist GG, Gyurus E, Green A, Soltesz G. 2009. Incidence trends for childhood type 1 diabetes in Europe during 1989-2003 and predicted new cases 2005-20: A multicentre prospective registration study. Lancet 373: 2027-2033.

Pescovitz MD, Greenbaum CJ, Krause-Steinrauf H, Becker DJ, Gitelman SE, Goland R, Gottlieb PA, Marks JB, McGee PF, Moran AM, et al. 2009. Rituximab, Blymphocyte depletion, and preservation of $\beta$-cell function. N Engl J Med 361: 2143-2152.

Petrilli V, Dostert C, Muruve DA, Tschopp J. 2007. The inflammasome: A danger sensing complex triggering innate immunity. Curr Opin Immunol 19: 615-622.

Poitout V, Robertson RP. 2008. Glucolipotoxicity: Fuel excess and $\beta$-cell dysfunction. Endocr Rev 29: 351-366.

Pozzilli P, Guglielmi C. 2009. Double diabetes: A mixture of type 1 and type 2 diabetes in youth. Endocr Dev 14: 151166.

Pukel C, Baquerizo H, Rabinovitch A. 1988. Destruction of rat islet cell monolayers by cytokines. Synergistic interactions of interferon- $\gamma$, tumor necrosis factor, lymphotoxin, and interleukin 1. Diabetes 37: 133-136.

Qatanani M, Lazar MA. 2007. Mechanisms of obesity-associated insulin resistance: Many choices on the menu. Genes Dev 21: 1443-1455.

Richardson SJ, Willcox A, Bone AJ, Foulis AK, Morgan NG. 2009. Islet-associated macrophages in type 2 diabetes. $D i$ abetologia 52: 1686-1688.

Rutkowski JM, Davis KE, Scherer PE. 2009. Mechanisms of obesity and related pathologies: The macro- and microcirculation of adipose tissue. FEBS J 276: 5738-5746.

Saberi M, Woods NB, de Luca C, Schenk S, Lu JC, Bandyopadhyay G, Verma IM, Olefsky JM. 2009. Hematopoietic cell-specific deletion of toll-like receptor 4 ameliorates hepatic and adipose tissue insulin resistance in highfat-fed mice. Cell Metab 10: 419-429.

Saltiel AR, Kahn CR. 2001. Insulin signalling and the regulation of glucose and lipid metabolism. Nature 414: 799_ 806.

Sauter NS, Schulthess FT, Galasso R, Castellani LW, Maedler K. 2008. The antiinflammatory cytokine interleukin-1 receptor antagonist protects from high-fat diet-induced hyperglycemia. Endocrinology 149: 2208-2218.

Savill J, Fadok V. 2000. Corpse clearance defines the meaning of cell death. Nature 407: 784-788.

Savill J, Dransfield I, Gregory C, Haslett C. 2002. A blast from the past: Clearance of apoptotic cells regulates immune responses. Nat Rev Immunol 2: 965-975.

Shi H, Kokoeva MV, Inouye K, Tzameli I, Yin H, Flier JS. 2006. TLR4 links innate immunity and fatty acid-induced insulin resistance. J Clin Invest 116: 3015-3025.

Shoelson SE, Lee J, Goldfine AB. 2006. Inflammation and insulin resistance. J Clin Invest 116: 1793-1801.

Shulman GI. 2000. Cellular mechanisms of insulin resistance. J Clin Invest 106: 171-176.

Solinas G, Vilcu C, Neels JG, Bandyopadhyay GK, Luo JL, Naugler W, Grivennikov S, Wynshaw-Boris A, Scadeng
M, Olefsky JM, et al. 2007. JNK1 in hematopoietically derived cells contributes to diet-induced inflammation and insulin resistance without affecting obesity. Cell Metab 6: 386-397.

Stienstra R, Joosten LA, Koenen T, van Tits B, van Diepen JA, van den Berg SA, Rensen PC, Voshol PJ, Fantuzzi G, Hijmans A, et al. 2010. The inflammasome-mediated caspase- 1 activation controls adipocyte differentiation and insulin sensitivity. Cell Metab 12: 593-605.

Strissel KJ, Stancheva Z, Miyoshi H, Perfield JW II, DeFuria J, Jick Z, Greenberg AS, Obin MS. 2007. Adipocyte death, adipose tissue remodeling, and obesity complications. Diabetes 56: 2910-2918.

Taniguchi CM, Emanuelli B, Kahn CR. 2006. Critical nodes in signalling pathways: Insights into insulin action. Nat Rev Mol Cell Biol 7: 85-96.

Tellez N, Montolio M, Biarnes M, Castano E, Soler J, Montanya E. 2005. Adenoviral overexpression of interleukin-1 receptor antagonist protein increases $\beta$-cell replication in rat pancreatic islets. Gene Ther 12: 120-128.

Thorn LM, Forsblom C, Fagerudd J, Thomas MC, Pettersson-Fernholm K, Saraheimo M, Waden J, Ronnback M, Rosengard-Barlund M, Bjorkesten CG, et al. 2005. Metabolic syndrome in type 1 diabetes: Association with diabetic nephropathy and glycemic control (the FinnDiane study). Diabetes Care 28: 2019-2024.

Unger RH. 1995. Lipotoxicity in the pathogenesis of obesity-dependent NIDDM. Genetic and clinical implications. Diabetes 44: 863-870.

Uno S, Imagawa A, Okita K, Sayama K, Moriwaki M, Iwahashi $\mathrm{H}$, Yamagata K, Tamura S, Matsuzawa Y, Hanafusa T, et al. 2007. Macrophages and dendritic cells infiltrating islets with or without $\beta$ cells produce tumour necrosis factor- $\alpha$ in patients with recent-onset type 1 diabetes. $D i$ abetologia 50: 596-601.

Usher MG, Duan SZ, Ivaschenko CY, Frieler RA, Berger S, Schutz G, Lumeng CN, Mortensen RM. 2010. Myeloid mineralocorticoid receptor controls macrophage polarization and cardiovascular hypertrophy and remodeling in mice. J Clin Invest 120: 3350-3364.

Vandanmagsar B, Youm YH, Ravussin A, Galgani JE, Stadler K, Mynatt RL, Ravussin E, Stephens JM, Dixit VD. 2011 The NLRP3 inflammasome instigates obesity-induced inflammation and insulin resistance. Nat Med 17: 179188.

Vats D, Mukundan L, Odegaard JI, Zhang L, Smith KL, Morel CR, Greaves DR, Murray PJ, Chawla A. 2006. Oxidative metabolism and PGC- $1 \beta$ attenuate macrophagemediated inflammation. Cell Metab 4: 13-24.

Weisberg SP, McCann D, Desai M, Rosenbaum M, Leibel RL, Ferrante AW Jr. 2003. Obesity is associated with macrophage accumulation in adipose tissue. J Clin Invest 112: 1796-1808.

Weisberg SP, Hunter D, Huber R, Lemieux J, Slaymaker S, Vaddi K, Charo I, Leibel RL, Ferrante AW Jr. 2006. CCR2 modulates inflammatory and metabolic effects of high-fat feeding. J Clin Invest 116: 115-124.

Wellen KE, Hotamisligil GS. 2005. Inflammation, stress, and diabetes. J Clin Invest 115: 1111-1119.

Wilkin TJ. 2009. The accelerator hypothesis: A review of the evidence for insulin resistance as the basis for type I as well as type II diabetes. Int J Obes (Lond) 33: 716-726. 
J.I. Odegaard and A. Chawla

Winer S, Chan Y, Paltser G, Truong D, Tsui H, Bahrami J, Dorfman R, Wang Y, Zielenski J, Mastronardi F, et al. 2009. Normalization of obesity-associated insulin resistance through immunotherapy. Nat Med 15: 921-929.

Winer DA, Winer S, Shen L, Wadia PP, Yantha J, Paltser G, Tsui H, Wu P, Davidson MG, Alonso MN, et al. 2011. B cells promote insulin resistance through modulation of $\mathrm{T}$ cells and production of pathogenic IgG antibodies. Nat Med 17: 610-617.

Wu D, Molofsky AB, Liang HE, Ricardo-Gonzalez RR, Jouihan HA, Bando JK, Chawla A, Locksley RM. 2011. Eosinophils sustain adipose alternatively activated macrophages associated with glucose homeostasis. Science 332: $243-247$.
Xu H, Barnes GT, Yang Q, Tan G, Yang D, Chou CJ, Sole J, Nichols A, Ross JS, Tartaglia LA, et al. 2003. Chronic inflammation in fat plays a crucial role in the development of obesityrelated insulin resistance. J Clin Invest 112: 1821-1830.

Xu P, Cuthbertson D, Greenbaum C, Palmer JP, Krischer JP. 2007. Role of insulin resistance in predicting progression to type 1 diabetes. Diabetes Care 30: 2314-2320.

Yuan M, Konstantopoulos N, Lee J, Hansen L, Li ZW, Karin M, Shoelson SE. 2001. Reversal of obesity- and diet-induced insulin resistance with salicylates or targeted disruption of Ikk $\beta$. Science 293: 1673-1677.

Zhou R, Tardivel A, Thorens B, Choi I, Tschopp J. 2010. Thioredoxin-interacting protein links oxidative stress to inflammasome activation. Nat Immunol 11: 136-140. 


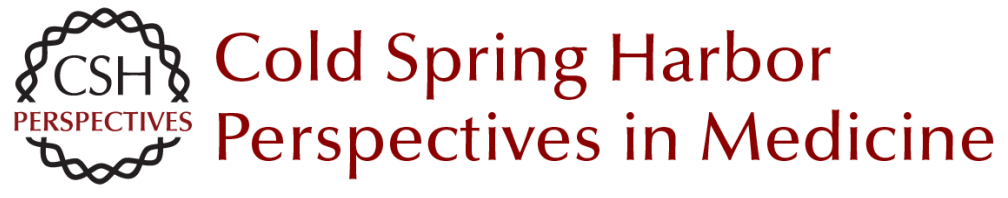

\section{Connecting Type 1 and Type 2 Diabetes through Innate Immunity}

Justin I. Odegaard and Ajay Chawla

Cold Spring Harb Perspect Med 2012; doi: 10.1101/cshperspect.a007724 originally published online January 10, 2012

\section{Subject Collection Type I Diabetes}

The Pathogenesis and Natural History of Type 1 Diabetes

Mark A. Atkinson

Do MHCII-Presented Neoantigens Drive Type 1

Diabetes and Other Autoimmune Diseases?

Philippa Marrack and John W. Kappler

Clinical Immunologic Interventions for the

Treatment of Type 1 Diabetes

Lucienne Chatenoud, Katharina Warncke and

Anette-G. Ziegler

Update on Islet Transplantation

Michael McCall and A.M. James Shapiro

Immunologic and Metabolic Biomarkers of $\beta$-Cell

Destruction in the Diagnosis of Type 1 Diabetes Jasmin Lebastchi and Kevan C. Herold

Advancing Animal Models of Human Type 1

Diabetes by Engraftment of Functional Human

Tissues in Immunodeficient Mice

Michael A. Brehm, Alvin C. Powers, Leonard D.

Shultz, et al.

Breakdown in Peripheral Tolerance in Type 1

Diabetes in Mice and Humans

Lukas T. Jeker, Hélène Bour-Jordan and Jeffrey $A$. Bluestone

Antigen-Specific Therapeutic Approaches in Type 1 Diabetes

Xavier Clemente-Casares, Sue Tsai, Carol Huang, et al.
Humoral Autoimmunity in Type 1 Diabetes:

Prediction, Significance, and Detection of Distinct

Disease Subtypes

Massimo Pietropaolo, Roberto Towns and George

S. Eisenbarth

Endoplasmic Reticulum Stress, Pancreatic $\beta$-Cell

Degeneration, and Diabetes

Feroz R. Papa

Islet Autoantigens: Structure, Function,

Localization, and Regulation

Peter Arvan, Massimo Pietropaolo, David Ostrov, et al.

Environmental Triggers of Type 1 Diabetes Mikael Knip and Olli Simell

Generating $\beta$ Cells from Stem Cells--The Story So

Far Matthias Hebrok

Antigen Targets of Type 1 Diabetes Autoimmunity Bart O. Roep and Mark Peakman

Connecting Type 1 and Type 2 Diabetes through Innate Immunity Justin I. Odegaard and Ajay Chawla

The Hygiene Hypothesis: An Explanation for the Increased Frequency of Insulin-Dependent Diabetes Jean-François Bach and Lucienne Chatenoud

For additional articles in this collection, see http://perspectivesinmedicine.cshlp.org/cgi/collection/ 